\title{
Smart Production of Lipids as Bio-Fuel in Spirulina Platensis (=Arthrospira Fusiformis), and Bio-Oxygen and Bio-Electricity in Media Cultured in Supernatant of Digested Poultry Waste
}

\author{
M.A. Satter ${ }^{1}$, Maisha F. Orpa ${ }^{2}$, M. Ahsan B. Habib \\ ${ }^{1}$ Bangamata Sheikh Fajjilatunnesha Mujib Science and Technology University, Jamalpur, Melandah, Bangladesh \\ ${ }^{2,3}$ Department of Aquaculture, Faculty of Fisheries, Bangladesh Agricultural University, Mymensingh 2202, Bangladesh
}

\begin{abstract}
An experiment was conducted to evaluate growth performances and production of bio-fuel of Spirulina platensis (Gomont), and bio-oxygen and bio-electricity of culture media in supernatant of three different amount of digested poultry waste (DPW), and Kosaric medium (KM) as control. Three different amounts (concentrations) such as $2.0,4.0$ and $6.0 \mathrm{~g} / \mathrm{L}$ poultry waste were allowed to digest under aeration. After 17 days, $700 \mathrm{ml}$ grayish coloured supernatant was taken with addition of $9.0 \mathrm{~g} / \mathrm{L}$ $\mathrm{NaHCO}_{3}$ and $0.50 \mathrm{ml} / 1$ micronutrient in $2.0 \mathrm{~L}$ conical flask with three replications and then autoclaved. Spirulina was inoculated to grow in these three treatments including KM (Control) after 72 hours of autoclave and then allowed to grow for a period of 14 days. This duration was estimated through repeated growth trials. The cell weight of spirulina was attained a maximum of $12.58 \pm$ $1.25 \mathrm{mg} / \mathrm{L}$ (dry wt. basis) in $\mathrm{KM}$ followed by $11.46 \pm 1.03,9.16 \pm 0.84$ and $8.13 \pm 0.73 \mathrm{mg} / \mathrm{L}$ in supernatant of 4.0, 2.0 and 6.0 $\mathrm{g} / \mathrm{L}$ DPW, respectively on the 10th day of culture. Similar trend was also observed in the cases of optical density of the media contained spirulina, chlorophyll a content $(\mathrm{mg} / \mathrm{L})$, cell weight, total biomass $(\mathrm{mg} / \mathrm{l})$ and specific growth rates on the basis of cell weight and chlorophyll a. Cell weight of spirulina grown in these media had highly significant $(\mathrm{P}<0.01)$ correlation with the chlorophyll a content $(r=0.993)$ of spirulina. Crude protein of spirulina grown in supernatant of DPW was lower than that of spirulina cultured in KM. Crude lipids as bio-fuel of spirulina cultured in supernatant of $4.0 \mathrm{~g} / \mathrm{L}$ DPW was almost three times higher than that of spirulina grown in KM which may be due to high phospholipids bioaccumulation. Phosphate-P was decreased in media of DPW due to its use for high lipids biosynthesis as phospholipids. Bio-oxygen was produced higher ranged from $2.1 \pm$ $11 \mathrm{mg} / \mathrm{L}$ on initial day to $10.20 \pm 0.54 \mathrm{mg} / \mathrm{L}$ on 10th day grown in supernatant of $4.0 \mathrm{~g} / \mathrm{L} \mathrm{DPW}$ media. Bio-electricity as green electricity ranged from $135 \pm 4$ on initial day to $284 \pm 7 \mathrm{mV}$ on 10th day when spirulina cultured in supernatant of $4.0 \mathrm{~g} / \mathrm{L} \mathrm{DPW}$ which was higher than grown in other media. $\mathrm{pH}$ followed the similar trend like bio-oxygen and bio-electricity. It was found that the production of bio-oxygen, bio-fuel and bio-electricity had direct relation with $\mathrm{pH}$ in culture media of spirulina. Therefore, mass production of Spirulina platensis might be done in supernatant of $4.0 \mathrm{~g} / \mathrm{L}$ digested poultry waste to get high total lipids as bio-fuel, bio-electricity and bio-oxygen.
\end{abstract}

KEYWORDS: Spirulina platensis; poultry waste; bio-oxygen; bio-fuel; bio-electricity

\section{INTRODUCTION}

Microalgae are potential source of protein, amino acids, lipids, PUFAs, minerals in fish diets, which can replace these nutrients if incorporated in proper amounts [1]. The number of species of microalgae is estimated to be 22,000-26,000 out of which about 50 have been studied in details with regard to their biochemistry and echo-physiology [2,3]. Among microalgae, Spirulina platensis (Gomont) renamed as Arthrospira fusiformis (Voronichin) Komarek and Loud is a multicellular, helical shaped, an important Cyanobacteria and also known as blue-green algae. They are very small and microscopic and 300-500 $\mu \mathrm{m}$ in length. Spirulina are very important and only the beneficial blue-green algae contain high protein (around 55-70\%) [3,4,5,6,7] and lipids (18-20\%) when their successful production found in sago waste water [4], fermented Thai rice noodle factory waste water [8], agroindustrial wastes [9], digested liquid rice starch [10], digested rotten orange [11], digested rotten potato [12], digested rotten apple [13], digested wax gourd [14], biscuit factory waste [15], bio-matters industrially produced [16] and in some selected media [17]. 


\section{International Journal of Current Science Research and Review}

ISSN: 2581-8341

Volume 04 Issue 04 April 2021

DOI: 10.47191/ijcsrr/V4-i4-08, Impact Factor: 5.825

IJCSRR@ 2021

Www.ijcsrr.org

Spirulina contain high amount of poly-unsaturated fatty acids (PUFAs) (32\% of its total lipids) [7,18,19], $\gamma$-linolenic acid about $36 \%$ of total PUFAs $[16,20]$ and rich in antioxidants $[21,22,23,24]$.

Spirulina have all essential minerals and works as a chelatizing agent which $[3,25,26]$ removes chromium [27] and reactive arsenic $[13,26,27]$ and heavy metals from the environment $[6,26,28]$. According to some researchers, one gram of spirulina protein is equivalent to one kilogram of assorted vegetables [22]. The amino acid composition of spirulina protein ranked high among the best plant products in the world even more than that of soyabean [22,29]. Spirulina are used as a potential health food for humans and other animals $[23,30,31,32,33]$. The spirulina species are used to replace fish meal in diets of fish post-larvae/fry which resulted good growth performances [7,18,34,35].

In Bangladesh, a lot of waste materials and effluents of agro-industrial products are available which have nutritional values [28,36,37]. Among these, waste effluents discharged from sugar mills, fertilizer factory, biscuit factory, sago factory, poultry industry etc. are important $[35,36,37]$. Spirulina usually reduce chemical oxygen demand (COD), ammoniacal-N, and available-P upto $98.00,99.90$ and $99.40 \%$, respectively from culture system [4]. The above results show the way to use other wastes by spirulina to biosynthesize essential nutrients. Some other media were developed in the laboratory for domestic scale culture of spirulina in Bangladesh [38]. It is proved that micro-algal fuel cells (MFCs) would provide a source of green electricity or bioelectricity to generate power and bio-fuel from lipids of spirulina by [39] using domestic and industrial wastes [40,41] due to photosynthesis. In photosynthesis, light energy splits water molecules into bio-oxygen, protons and electrons which usually known as bio-electricity [42].

Among the wastes, poultry waste may help for biosynthesis of protein, lipids and carbohydrate. Poultry waste as an inexpensive medium is also one the major pollutants like other agro-industrial wastes. Huge amount of poultry waste approximately 1.8 million $\mathrm{kg}$ is discharging in the country every year from 90,000-1,00,000 poultry farms [43]. This waste contains considerable amount of nitrogen, and high amount of calcium and phosphorus due to use of mollusk shell powder in feed of poultry [43]. This phosphorus may help to produce high phospholipids in microalgae and ultimately increase the amount of total lipids $[18,43]$. However, poultry waste is easily available nationwide and collected all the time. The information related to this work is scanty in the country. Therefore, the present study was conducted to culture spirulina in supernatant of this inexpensive waste material to record the growth performances of spirulina, to produce high lipids in spirulina, bio-oxygen and bio-electricity in media with the following specific objectives:

a) To evaluate the growth performances of spirulina grown in supernatant of digested poutry waste;

b) To analyze growth parameters, and

c) To produce bio-fuel as lipids, bio-oxygen and bio-electricity in the culture system of spirulina.

\section{MATERIALS AND METGODS}

Poultry waste was collected from a nearby poultry farm and then sun-dried for three days and packed in polythene bag for chemical analyses and used to prepare medium for spirulina culture. The proximate composition of poultry waste such as moisture, crude protein, crude lipids, ash and nitrogen free extract (NFE) were analyzed in triplicates following the standard methods [44] in the Fish Nutrition Laboratory, Department of Aquaculture, Bangladesh Agricultural University (BAU), Mymensingh, Bangladesh. Characteristics of poultry waste before and after digestion are shown in Tables 3 and 4, respectively.

\section{a. Maintenance of pure stock culture of spirulina}

Pure stock culture of spirulina was maintained in the laboratory in Kosaric medium (KM) [45]. Growth of spirulina was monitored at every alternate day and was checked under a microscope to confirm its purity following the keys of [46,47,48,49].

\section{b. Preparation of supernatant of poultry waste}

For perpetration of poultry waste medium, it was first collected from a local poultry farm, Mymensingh, Bangladesh and then screened through net (mesh size: $200 \mu \mathrm{m}$ ) to avoid solids, fibres and floating materials. Ten g/L dry poultry waste was allowed to decompose in $4.0 \mathrm{~L}$ of distilled water in $5.0 \mathrm{~L}$ glass bottle for 17 days under aerobic condition in the Live Food Culture laboratory (Table 1). Then a yellowish white coloured supernatant from bottle was filtered through Whatman filter paper of mesh size 0.45 $\mu \mathrm{m}$ to make free from suspended solids, and made three concentrations with distilled water at the rate of $2.0,4.0$ and $6.0 \mathrm{~g} / \mathrm{L}$ 


\section{International Journal of Current Science Research and Review}

ISSN: 2581-8341

Volume 04 Issue 04 April 2021

DOI: 10.47191/ijcsrr/V4-i4-08, Impact Factor: 5.825

IJCSRR@ 2021

WwW.ijesrr.org

decomposed poultry waste. Then $650 \mathrm{~mL}$ supernatant of three different concentrations were taken in $2.0 \mathrm{~L}$ flask with three replications. Sodium bicarbonate $(9.0 \mathrm{~g} / \mathrm{L})$ and micronutrient solution $(0.50 \mathrm{~mL} / \mathrm{L})$ were added in the flask to make the medium alkaline, mixed thoroughly and sterilized at $120^{\circ} \mathrm{C}$ for 15 minutes with moist heat by autoclave (Express Equipment, Dixon's Surgical Instrument Ltd.). After sterilization, the media were kept for 24 hrs to be sure whether any contamination before culture of microalgae.

\section{c. Preparation of Kosaric medium}

Kosaric medium (KM) was prepared for Spirulina platensis culture as a control. For the preparation of Kosaric medium, the mentioned amount (Table 2) of ingredients from no. 1 to 8 was weighed and taken in a $1.0 \mathrm{~L}$ conical flask. Then $0.5 \mathrm{ml}$ micronutrient solution was pipetted in the flask and distilled water was added to make the volume 1.0 L. Mixing, autoclaving and cooling were carried out pursuing the procedure used during the preparation of poultry waste media.

Table 1. Experimental design for Spirulina platensis culture using supernatant of three different concentrations of digested poultry waste.

\begin{tabular}{ll|l|l|l}
\hline Types of medium & Treatments & Replications & $\begin{array}{l}\text { Amounts of } \\
\text { poultry waste } \\
(\mathrm{g} / \mathrm{L})\end{array}$ & $\begin{array}{l}\text { Duration of culture } \\
\text { (days) }\end{array}$ \\
\hline Supernatant of & 1 & 3 & 2 & 14 \\
digested poultry waste & 2 & 3 & 4 & 14 \\
Kosaric medium & 3 & 3 & 6 & 14 \\
\hline
\end{tabular}

Table 2. Composition of Kosaric medium [45] for Spirulina platensis culture

\begin{tabular}{l|l|l}
\hline Sl. No. & Chemicals/compounds & $\begin{array}{l}\text { Concentration in stock solution } \\
\mathrm{g} / \mathrm{L}\end{array}$ \\
\hline 1 & $\mathrm{NaHCO}_{3}$ & 9.0 \\
2 & $\mathrm{~K}_{2} \mathrm{HPO}_{4}$ & 0.250 \\
3 & $\mathrm{NaNO}_{3}$ & 1.250 \\
4 & $\mathrm{~K}_{2} \mathrm{SO}_{4}$ & 0.50 \\
5 & $\mathrm{NaCl}_{6}$ & 0.50 \\
6 & $\mathrm{MgSO}_{4} 7 \mathrm{H}_{2} \mathrm{O}$ & 0.10 \\
7 & $\mathrm{CaCl}_{2}$ & 0.02 \\
8 & $\mathrm{FeSO}_{4} 2 \mathrm{H}_{2} \mathrm{O}$ & 0.005 \\
9 & $\mathrm{~A}_{5} \mathrm{micronutrient}$ & $0.5 \mathrm{~mL} / \mathrm{L}$ \\
& a) $\mathrm{A}_{5} \mathrm{micronutrient}$ & $\mathrm{g} / \mathrm{L}$ \\
& i) $\mathrm{H}_{3} \mathrm{BO}_{4}$ & 2.86 \\
& ii) $\mathrm{MnCl}_{2} \cdot 4 \mathrm{H}_{2} \mathrm{O}$ & 1.81 \\
& iii) $\mathrm{ZnSO}_{4} 7 \mathrm{H}_{2} \mathrm{O}$ & 0.22 \\
& iv) $\mathrm{CuSO}_{4} \cdot 7 \mathrm{H}_{2} \mathrm{O}$ & 0.08 \\
& v) $\mathrm{MoO}_{3}$ & 0.01 \\
& vi) $\mathrm{CoCl}_{2} .6 \mathrm{H}_{2} \mathrm{O}$ & 0.01 \\
\hline
\end{tabular}

\section{d. Culture of spirulina (Spirulina platensis) in supernatant of DPW and KM}

Four treatments, $650 \mathrm{~mL}$ of supernatant of digested poultry waste (DPW) of three different concentrations $(2.0,4.0$ and $6.0 \mathrm{~g} / \mathrm{L})$ and one Kosaric medium $(\mathrm{KM})$ as control each with three replications were taken in $2.0 \mathrm{~L}$ conical flasks and used to grow microalgae, S. platensis. All the glass wares used in the experiment were sterilized with dry heat at $70^{\circ} \mathrm{C}$ overnight. Spirulina was 


\section{International Journal of Current Science Research and Review}

ISSN: 2581-8341

Volume 04 Issue 04 April 2021

DOI: 10.47191/ijcsrr/V4-i4-08, Impact Factor: 5.825

IJCSRR@ 2021

WWW.ijesrr.org

inoculated in each culture flask from a culture containing 10\% spirulina suspension (Optical density at $620 \mathrm{~nm}=0.20$ ) [2]. All the flasks were kept under fluorescent light (TFC, FL-40 SD/38 day light, Taiwan) in light: dark (12h:12h) conditions in Live Food Culture laboratory. These culture flasks were continuously aerated using electric aerator (Aquarium Pump NS-8200). Twelve subsamplings of $20 \mathrm{~mL}$ each were taken at every alternative day from 12 flask to record dry cell weight and chlorophyll a content of spirulina and properties of culture media. All the microalgal samples were collected just before reaching the stationary phase. The stationary phase was recorded giving two growth trials of spirulina and then final experiment was conducted to collect spirulina before stationary phase. These samples were used to collect spirulina for the analyses of growth parameters and proximate composition of spirulina [44]. All the analyses were done following the methods given by [2,44]. Estimation of cell weight, chlorophyll $\underline{a}$, specific growth rates (SGRs) on the basis of dry weight, chlorophyll a content and total biomass of spirulina were calculated using the methods given by [2]. The physico-chemical properties of supernatant of digested poultry waste and leftover liquid residue were analyzed using different chemicals and equipments. These properties such as $\mathrm{pH}$, total suspended solids, total dissolved solids, total alkalinity, nitarte- $\mathrm{N}\left(\mathrm{NO}_{3}-\mathrm{N}\right)$ and phosphate-P $\left(\mathrm{PO}_{4}-\mathrm{P}\right)$ were analyzed in the laboratory of the Department of Aquaculture, BAU, Mymensingh following [2].

\section{e. Estimation of bio-fuel, bio-oxygen and bio-electricity from culture media of spirulina}

Bio-oxygen $(\mathrm{mg} / \mathrm{L})$ and bio-electricity $(\mathrm{mV})$ of culture media were recorded by digital meter (HEQEP CP 6014 G2) [50]. Bio-fuel as lipids of spirulna was estimated using ether extraction method from the sample [44].

\section{f. Statistical analysis}

Analysis of variance (ANOVA) of mean cell weight and chlorophyll a , and crude protein, crude lipids and ash of S. platensis cultured in different media (Treatments) were done and to find whether any significant difference among treatment means was done by Tukey test using statistical package following [51].

\section{RESULTS AND DISCUSSION}

Poultry waste was dense liquid (semi-liquid) contained high amount of total solids, chemical oxygen demand (COD), pH, phosphate-P and alkalinity (Table 3). The amount of total solids and COD were decreased drastically after digestion (Table 4). It contained high percentage of moisture, ash, \% nitrogen and denatured nitrogen free extract (Table 5). Most of the animal based wastes specially agro-industries contain high amount of $\mathrm{pH}$, available $\mathrm{N}$, available $\mathrm{P}$, total solids, COD and total $\mathrm{N}$ which agrees with the present findings of $[9,6,28,36,52]$. Spirulina platensis, very nutritious blue-green microalgae has grown very well in supernatant of aerobically digested $4.0 \mathrm{~g} / \mathrm{l}$ poultry waste. During the study, $\mathrm{pH}$ showed almost an increasing trend in culture media except in supernant of $2.0 \mathrm{~g} / \mathrm{l} \mathrm{DPW}$ (Fig. 1). The decomposed agro-industrial waste help to grow microalgae as chlorella and spirulina, and mosquito larvae due to presence of high nutrients, $\mathrm{pH}$ values and chemical oxygen demand which has the similarity with the present findings $[4,8,10,11,13,53]$. Bio-oxygen (Dissolved oxygen) was found to increase gradually upto 10th day of culture and then decreased in most of the cases (Fig. 2).

It has been observed that available $\mathrm{P}\left(\mathrm{PO}_{4}-\mathrm{P}\right)$ was gradually decreased up to highest peak of growth (Fig. 3) where available $\mathrm{N}$ (Nitrate-N) did not follow a definite trend (Fig. 4). Phosphate-P (Available P) was gradually decreased in amount up to 8th day in the culture of supernatant of $2.0 \mathrm{~g} / \mathrm{L}$ digested poultry waste (DPW) contained spirulina and again increased from 10th day up to 14th day of culture. But it was found to decrease from first day $(46.80 \pm 4.70 \mathrm{~g} / \mathrm{l})$ of experiment up to 10 th day $(15.40 \pm 1.60 \mathrm{~g} / \mathrm{L})$ but increased from 12th to 14th day of experiment in the culture of 4.0 and $6.0 \mathrm{~g} / \mathrm{l} \mathrm{DPW}$, and KM contained spirulina (Fig. 3). Both available $\mathrm{N}$ and available $\mathrm{P}$ were utilized by spirulina during its growth and ultimately these were decreased as spirulina increased up to the exponential phase of growth [37,54,55].

Optical density of media contained spirulina and cell weight and chlorophyll a of spirulina grown in supernatant of 4.0 g/L digested poultry waste significantly higher $(\mathrm{P}<0.05)$ than those of spirulina cultured in other media except KM (Table 6, Figs. 5, 6 and 7). The specific growth rates on the basis of cell weight and chlorophyll a of spirulina cultured in supernatant of $4.0 \mathrm{~g} / \mathrm{L}$ poultry waste had significant $(\mathrm{P}<0.05)$ differences from those of spirulina grown in other media except KM (Table 6). The growth parameters of $S$. platensis grown in the supernatant of digested $4.0 \mathrm{~g} / \mathrm{L}$ poultry waste were higher than other cultures in the supernatant of 2.0 and $6.0 \mathrm{~g} / \mathrm{L}$ digested poultry waste (Figs. 5, 6 and 7) which might be due to appropriate nutrient content and 


\section{International Journal of Current Science Research and Review}

ISSN: 2581-8341

Volume 04 Issue 04 April 2021

DOI: 10.47191/ijcsrr/V4-i4-08, Impact Factor: 5.825

IJCSRR@ 2021

Www.ijcsrr.org

other environmental parameters that agree with the findings of [6,9,16,56,57]. Cell weight was directly and highly significant $(\mathrm{P}<$ $0.01)$ and correlated $(r=0.993)$ with chlorophyll a of spirulina grown in supernatant of different digested poultry waste and Kosaric medium during the study (Fig. 9). [58] Found that S. platensis grown in digested mustard oil cake media in the concentrations of 3.0, 4.0, $0.5 \mathrm{mg} / \mathrm{l}$, and $\mathrm{KM}$, the maximum total biomass were 451.0, 614.33, 403.5 and $719.0 \mathrm{mg} / \mathrm{l}$, respectively. $[4,37]$ recorded almost similar cell weight and chlorophyll a of S. platensis when cultured in digested sago waste water which has the similarity with the present findings. Researchers $[13,59]$ recorded good growth of spirulina when cultured in supernatant of digested rotten potato and apple which almost agree with the present results.

A very important result was found that the crude lipids of spirulina were sharply increased when cultured in digested poultry waste (DPW) (Table 7). Spirulina contained higher amount (almost three times) of lipids when grown in supernatant of $4.0 \mathrm{~g} / \mathrm{L}$ DPW than 2.0 and $6.0 \mathrm{~g} / \mathrm{L} \mathrm{DPW}$, and Kosaric medium (Table 7). But, the crude protein of spirulina grown in PWM was lower than that cultured in Kosaric medium. Bioaccumulation of lipids in spirulina grown in poultry waste is a very promising result so that a high quality and quantity of lipids might be produced in plenty in spirulina when grown in the supernatant of digested poultry waste which may be due to phospholipids biosynthesized in spirulina. [4,8] also recorded high lipids in spirulina cultured in digested sago starch factory waste water and fermented waste water of noodle factory, respectively due to presence of high carbon.

Poultry waste contains high amount of phosphorus and calcium due to use of mollusk shell powder as source of minerals in poultry feed. This phosphorus came out from intestine with poultry waste (droppings) which ultimately helped to biosynthesis of phospholipids in spirulina. Almost three times more lipids may be biosynthesized in spirulina if it is cultured in the supernatant of 4.0 g/L digested poultry waste. But, [60] used in tapioca wastewater, [4] used digested sago starch factory waste water and [8] used waste water of Thai rice noodles factories to grow spirulina and recorded higher protein and lipids than cultured in Kosaric medium has similarity with the present findings in case of lipids. Nutrient manipulation in media helps to bioaccumulate lipids as bio-fuel in high amount [43] in microalgae. Nutrients manipulated with sodium acetate which may increase lipids biosynthesized in microalgae, Ankistrodesmus convolutes [61] and Chlorella vulgaris [62].

It was recorded that $\mathrm{pH}$, bio-oxygen and bio-electricity were found to increase gradually upto 10th day of culture and then decreased in most of the cases (Figs. 1,2 and 8) which has direct relation with gradual increment of optical density, cell weight and chlorophyll a of spirulina. Phosphate-P was decreased up to 10th day of culture which might be used due to bioaccumulation of lipids (Phospholipids) (Fig. 3). The production of bio-oxygen, bio-electricity, bio-fuel (lipids) were directly related with each other which were not similar when compared with other culture media $[4,40,41,42,50]$. The most important thing is the production of bio-fuel, bio-oxygen and bio-electricity using agroindustrial wastes for the production of spirulina $[4,42,50]$.

\section{CONCLUSION}

Therefore, it is recommended that spirulina may be grown in supernatant of $4.0 \mathrm{~g} / \mathrm{l}$ decomposed poultry waste (DPW) to increase percentage of lipids as bio-fuel in spirulina during mass or industrial production. With very little cost, these agroindustrial wastes may be prepared easily for media of culture which are available throughout the country. Thus poultry as well as other wastes may be used commercially and economically for the culture of S. platensis to produce high amount of lipids as bio-fuel, bio-oxygen and bio-electricity. The most important activity of spirulina is to use carbon and $\mathrm{CO}_{2}$ from the environment during photosynthesis for the production of very important things such as bio-oxygen, lipids as bio-fuel, protein and bio-electricity. It will also help to reduce at least partially the environmental pollution, carbon and $\mathrm{CO}_{2}$ emissioned from animal activities and industries, and ultimately minimize climate change which will create peaceful environment in the world.

\section{ACKNOWLEDGEMENTS}

Authors are grateful to International Foundation for Science, Stockholm, Sweden and BAURES, Bangladesh Agricultural University for funding to complete this work. The help and cooperation of laboratory technician of Nutrition Laboratory is thankfully acknowledged. 


\section{International Journal of Current Science Research and Review}

ISSN: 2581-8341

Volume 04 Issue 04 April 2021

DOI: 10.47191/ijcsrr/V4-i4-08, Impact Factor: 5.825

IJCSRR@ 2021

Www.ijcsrr.org

Table 3. Characteristics of raw poultry waste just after collection.

\begin{tabular}{c|l|l}
\hline S1. No. & Characteristics of raw poultry waste & \\
\hline 1 & Colour & Grayish \\
2 & Odour & Bad smell \\
3 & Structure & Semi-solid \\
4 & Temperature & $28.60-29.40^{\circ} \mathrm{C}$ \\
5 & $\mathrm{pH}$ & $8.0-8.21$ \\
6 & Total solids (TSS + TDS) & $89545.25-89877.50 \mathrm{mg} / \mathrm{L}$ \\
7 & Chemical oxygen demand (COD) & $45674-50255 \mathrm{mg} / \mathrm{L}$ \\
8 & Dissolved oxygen & $1.0-1.12 \mathrm{mg} / \mathrm{L}$ \\
9 & Alkalinity & $520-550 \mathrm{mg} / \mathrm{L}$ \\
10 & Available N & $2.50-2.65 \mathrm{mg} / \mathrm{L}$ \\
11 & Available P & $6.50-7.75 \mathrm{mg} / \mathrm{L}$ \\
12 & Total N & $5.50-5.75 \mathrm{mg} / \mathrm{L}$ \\
\hline
\end{tabular}

Table 4. Chemical properties of supernatant of poultry waste after 17 days of digestion in aerobic condition (values are mean \pm standard error, $\mathrm{n}=4$ )

\begin{tabular}{c|l|l}
\hline S1. No. & Characteristics of aerobically digested poultry waste & \\
\hline 1 & Temperature & $27.80-28.20^{\circ} \mathrm{C}$ \\
2 & Dissolved oxygen & $1.45-1.72 \mathrm{mg} / \mathrm{L}$ \\
3 & $\mathrm{pH}$ & $8.11-8.55$ \\
4 & Total solid (TSS + TDS) & $358-362 \mathrm{mg} / \mathrm{L}$ \\
5 & Chemical oxygen demand (COD) & $1560-1604 \mathrm{mg} / \mathrm{L}$ \\
6 & Alkalinity & $379-385 \mathrm{mg} / \mathrm{L}$ \\
7 & Nitrate N $\left(\mathrm{NO}_{3}-\mathrm{N}\right)$ & $4.90-5.10 \mathrm{mg} / \mathrm{L}$ \\
8 & Phosphate $\mathrm{P}\left(\mathrm{PO}_{3}-\mathrm{P}\right)$ & $5.06-5.35 \mathrm{mg} / \mathrm{L}$ \\
9 & Total N & $4.70-5.10 \mathrm{mg} / \mathrm{L}$ \\
\hline
\end{tabular}

Table 5. Chemical composition $(\%)$ of poultry waste on wet basis (values are mean \pm standard error, $n=4)$

\begin{tabular}{l|l|l|l|l}
\hline Moisture & $\%$ nitrogen & Ash & Crude fibre & $\begin{array}{l}\text { Denatured } \\
\text { NFE }\end{array}$ \\
\hline $17.26 \pm 0.50$ & $19.10 \pm 1.70$ & $24.80 \pm 1.85$ & $9.60 \pm 0.70$ & $29.10 \pm 1.25$
\end{tabular}

Table 6. Specific growth rates (SGRs) on the basis of cell weight, chlorophyll a and total biomass of Spirulina platensis grown in supernatant of different digested poultry waste (DPW) and Kosaric medium (values are mean \pm standard error, $\mathrm{n}=4$ )

\begin{tabular}{l|l|l|l|l}
\hline Parameters & $2.0 \mathrm{~g} / \mathrm{l} \mathrm{DPW}$ & $4.0 \mathrm{~g} / \mathrm{l} \mathrm{DPW}$ & $6.0 \mathrm{~g} / \mathrm{l} \mathrm{DPW}$ & $\mathrm{KM}$ \\
\hline $\begin{array}{l}\text { SGR of cell } \\
\text { weight }\end{array}$ & $0.28 \pm 0.019^{\mathrm{b}}$ & $0.31 \pm 0.025^{\mathrm{a}}$ & $0.26 \pm 0.016^{\mathrm{b}}$ & $0.32 \pm 0.024^{\mathrm{a}}$ \\
\hline $\begin{array}{l}\text { SGR of } \\
\text { Chlorophyll a }\end{array}$ & $0.25 \pm 0.018^{\mathrm{b}}$ & $0.29 \pm 0.024^{\mathrm{a}}$ & $0.24 \pm 0.015^{\mathrm{b}}$ & $0.30 \pm 0.025^{\mathrm{a}}$ \\
\hline $\begin{array}{l}\text { SGR of total } \\
\text { biomass }\end{array}$ & $0.77 \pm 0.063^{\mathrm{b}}$ & $0.82 \pm 0.065^{\mathrm{a}}$ & $0.77 \pm 0.040^{\mathrm{b}}$ & $0.82 \pm 0.060^{\mathrm{a}}$ \\
\hline
\end{tabular}

Figures in common letters in the same row do not differ significantly $(\mathrm{P}<0.01)$. 


\section{International Journal of Current Science Research and Review}

ISSN: 2581-8341

Volume 04 Issue 04 April 2021

DOI: 10.47191/ijcsrr/V4-i4-08, Impact Factor: 5.825

IJCSRR@ 2021

WWw.ijcsrr.org

Table 7. Proximate composition (\% in dry matter basis) of Spirulina platensis cultured in supernatant of three different digested poultry waste and control as Kosaric medium (values are mean \pm standard error, $n=4$ )

\begin{tabular}{l|c|c|c|c}
\hline Treatments & T1 $(2 \mathrm{~g} / \mathrm{l} \mathrm{DPW})$ & T2 $(4 \mathrm{~g} / 1 \mathrm{DPW})$ & $\mathrm{T} 3(6 \mathrm{~g} / \mathrm{l} \mathrm{DPW})$ & $\mathrm{T} 4(\mathrm{KM})$ \\
\hline Moisture & $8.33 \pm 0.10$ & $8.25 \pm 0.10$ & $8.28 \pm 0.10$ & $8.26 \pm 0.10$ \\
\hline Crude Protein & $48.15 \pm 0.90^{\mathrm{c}}$ & $48.40 \pm 0.80^{\mathrm{b}}$ & $48.20 \pm 0.80^{\mathrm{c}}$ & $58.50 \pm 0.70^{\mathrm{a}}$ \\
\hline Crude Lipid & $12.50 \pm 0.30^{\mathrm{b}}$ & $19.20 \pm 0.40^{\mathrm{a}}$ & $10.45 \pm 0.30^{\mathrm{b}}$ & $6.25 \pm 0.20^{\mathrm{c}}$ \\
\hline Ash & $14.50 \pm 0.30^{\mathrm{c}}$ & $16.60 \pm 0.40^{\mathrm{b}}$ & $17.25 \pm 0.50^{\mathrm{a}}$ & $14.12 \pm 0.40^{\mathrm{c}}$ \\
\hline NFE & $15.75 \pm 0.40^{\mathrm{a}}$ & $7.35 \pm 0.10^{\mathrm{c}}$ & $15.02 \pm 0.30^{\mathrm{a}}$ & $12.10 \pm 0.30^{\mathrm{b}}$ \\
\hline Crude Fibre & $0.73 \pm 0.04$ & $0.70 \pm 0.03$ & $0.75 \pm 0.04$ & $0.73 \pm 0.04$ \\
\hline
\end{tabular}

$* \mathrm{NFE}=100-$ (Moisture + Crude protein + Crude lipid + Ash). Figures in common letters in the same row do not differ significantly $(\mathrm{P}<0.01)$.

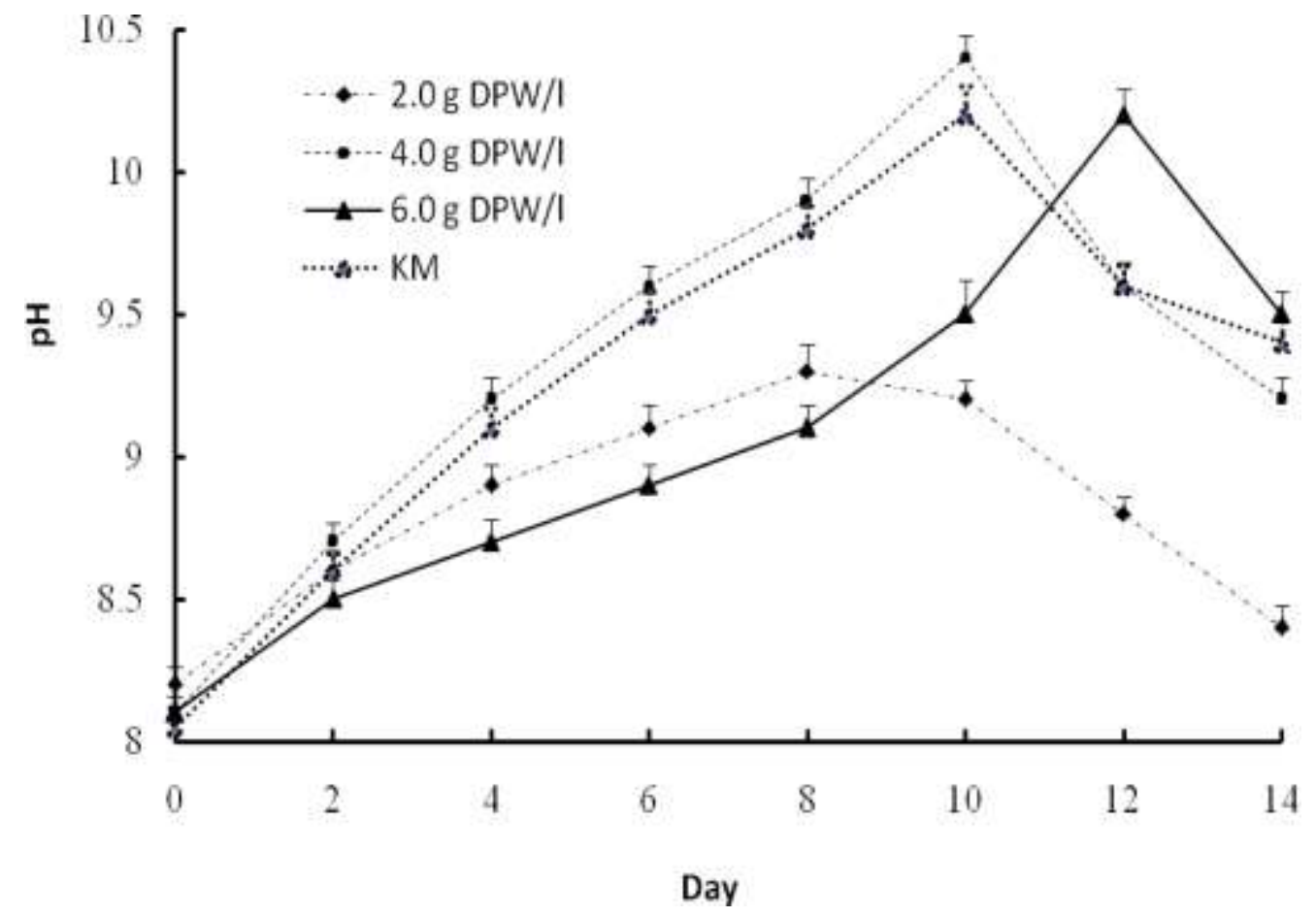

Fig. 1. Mean values of $\mathrm{pH}$ during culture of Spirulina platensis in supernatant of three different digested poultry waste, and Kosaric medium. Vertical represent standard errors. 


\section{International Journal of Current Science Research and Review}

ISSN: 2581-8341

Volume 04 Issue 04 April 2021

DOI: 10.47191/ijcsrr/V4-i4-08, Impact Factor: 5.825

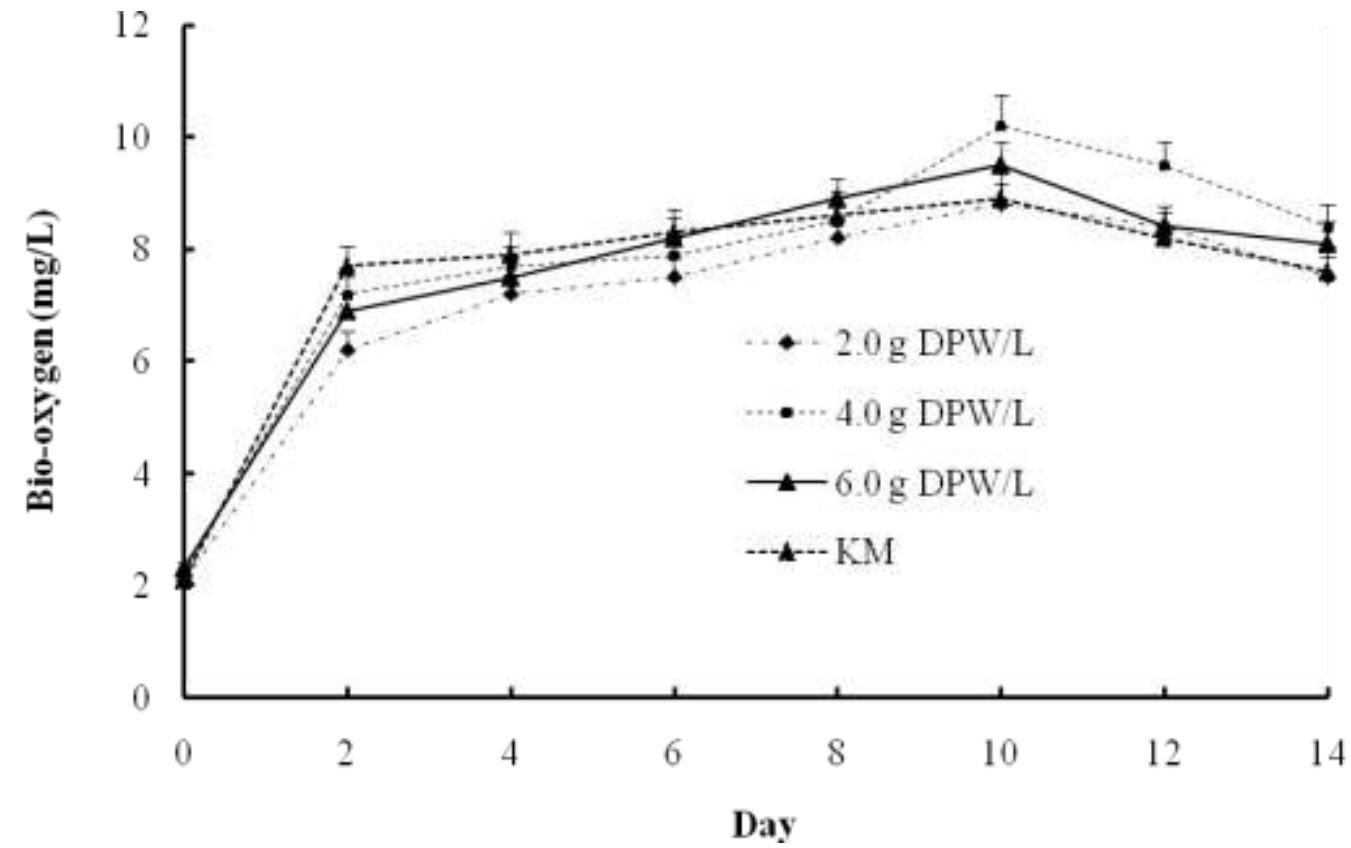

Fig. 2. Mean values of bio-oxygen (mg/L) during culture of Spirulina platensis in supernatant of three different digested poultry waste, and Kosaric medium. Vertical represent standard errors.

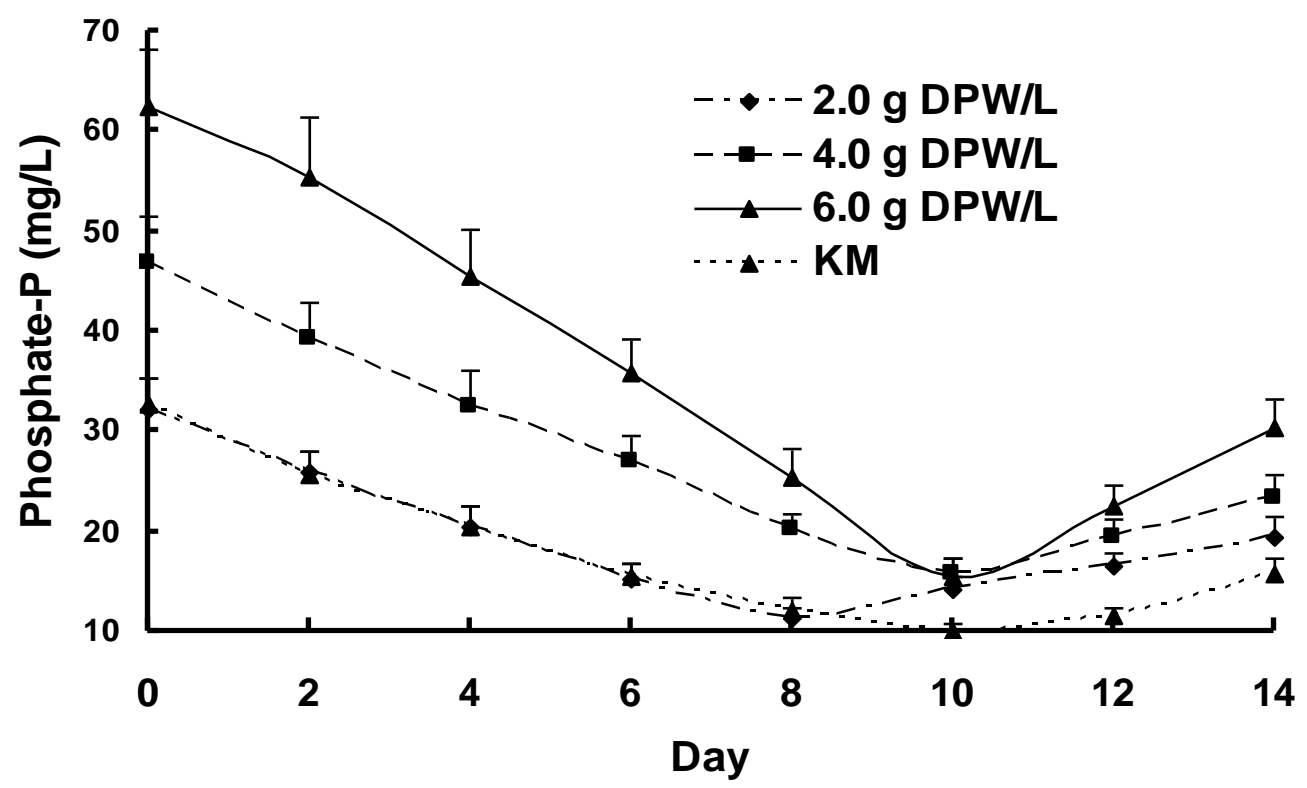

Fig. 3. Mean values of Phosphate-P (mg/l) during culture of Spirulina platensis in supernatant of three different digested poultry waste, and Kosaric medium. Vertical bars represent standard errors. 


\section{International Journal of Current Science Research and Review}

ISSN: 2581-8341

Volume 04 Issue 04 April 2021

DOI: 10.47191/ijcsrr/V4-i4-08, Impact Factor: 5.825

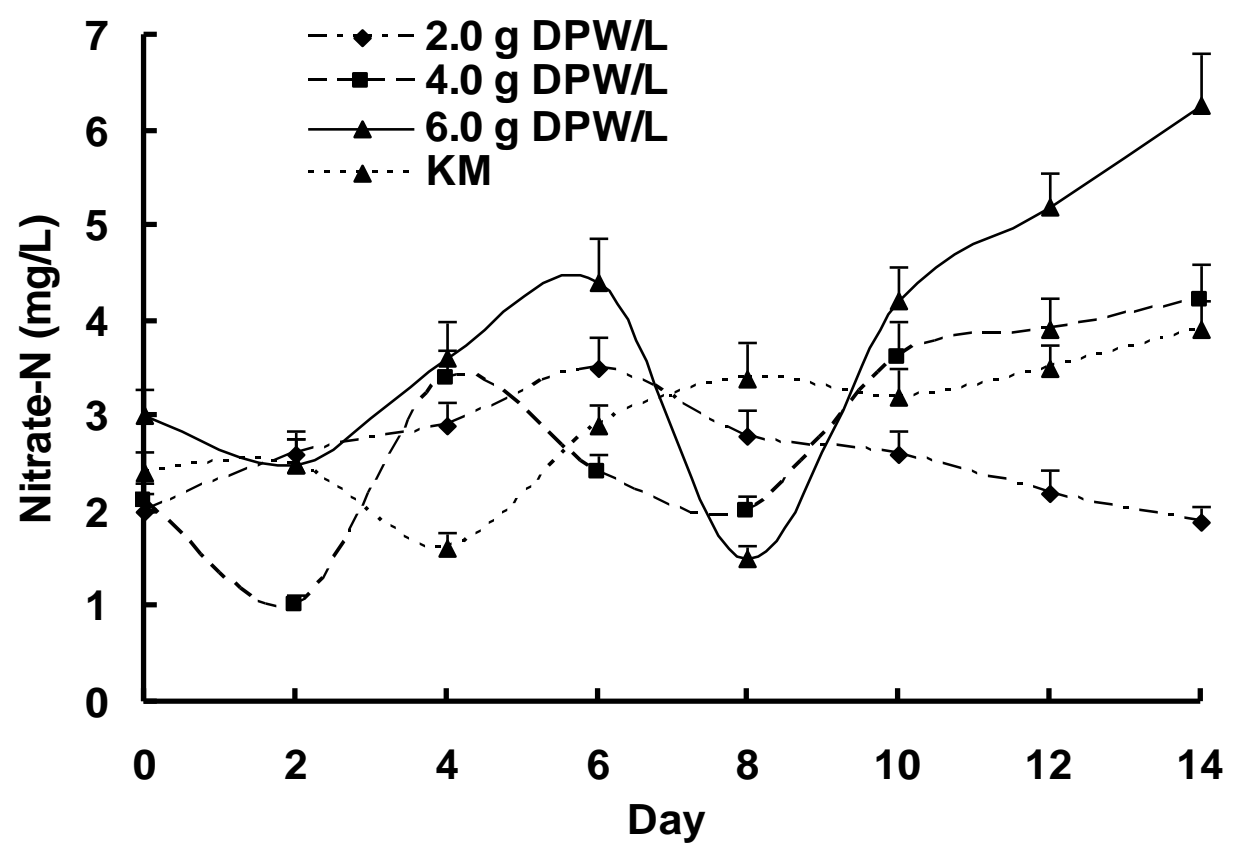

Fig. 4. Mean values of Nitrate-N (mg/l) during culture of Spirulina platensis in supernatant of three different digested poultry waste, and Kosaric medium. Vertical bars represent standard errors.

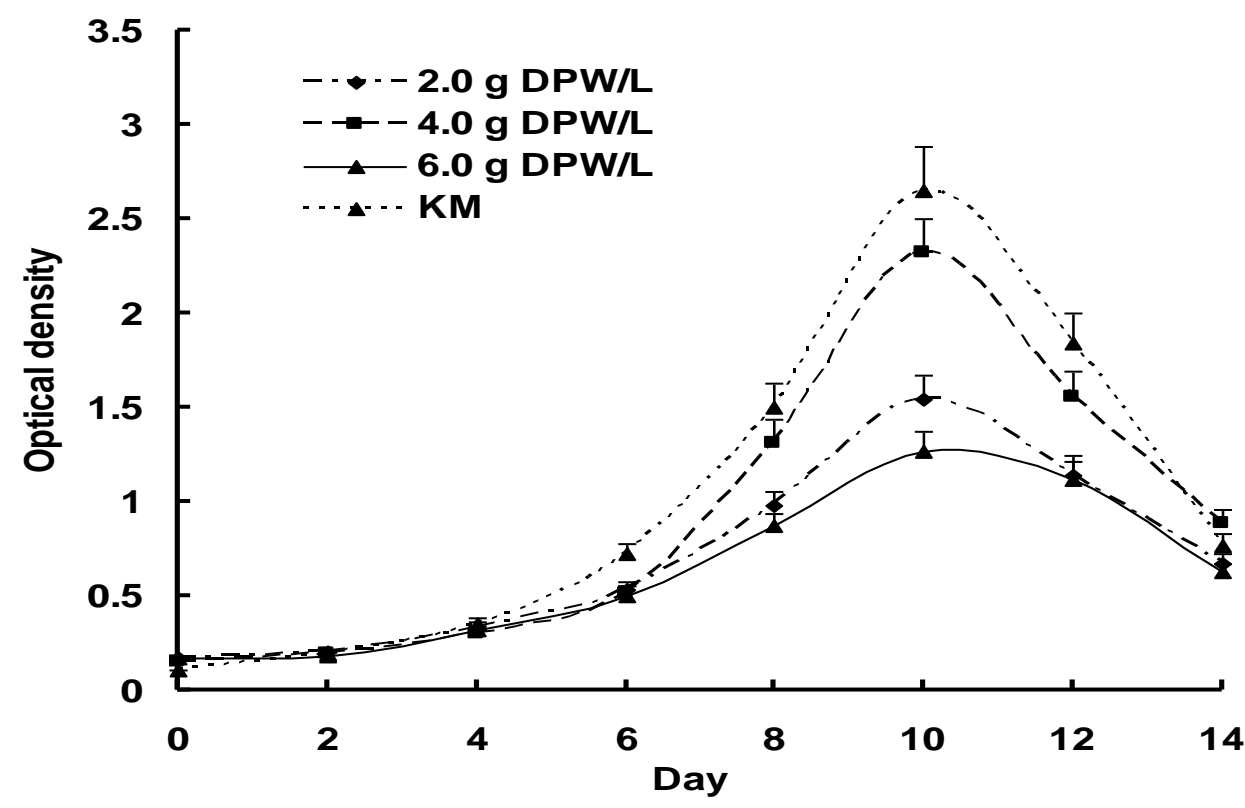

Fig. 5. Mean values of optical density of media contained Spirulina platensis in supernatant of three different digested poultry waste, and Kosaric medium. Vertical bars represent standard errors. 


\section{International Journal of Current Science Research and Review}

ISSN: 2581-8341

Volume 04 Issue 04 April 2021

DOI: 10.47191/ijcsrr/V4-i4-08, Impact Factor: 5.825

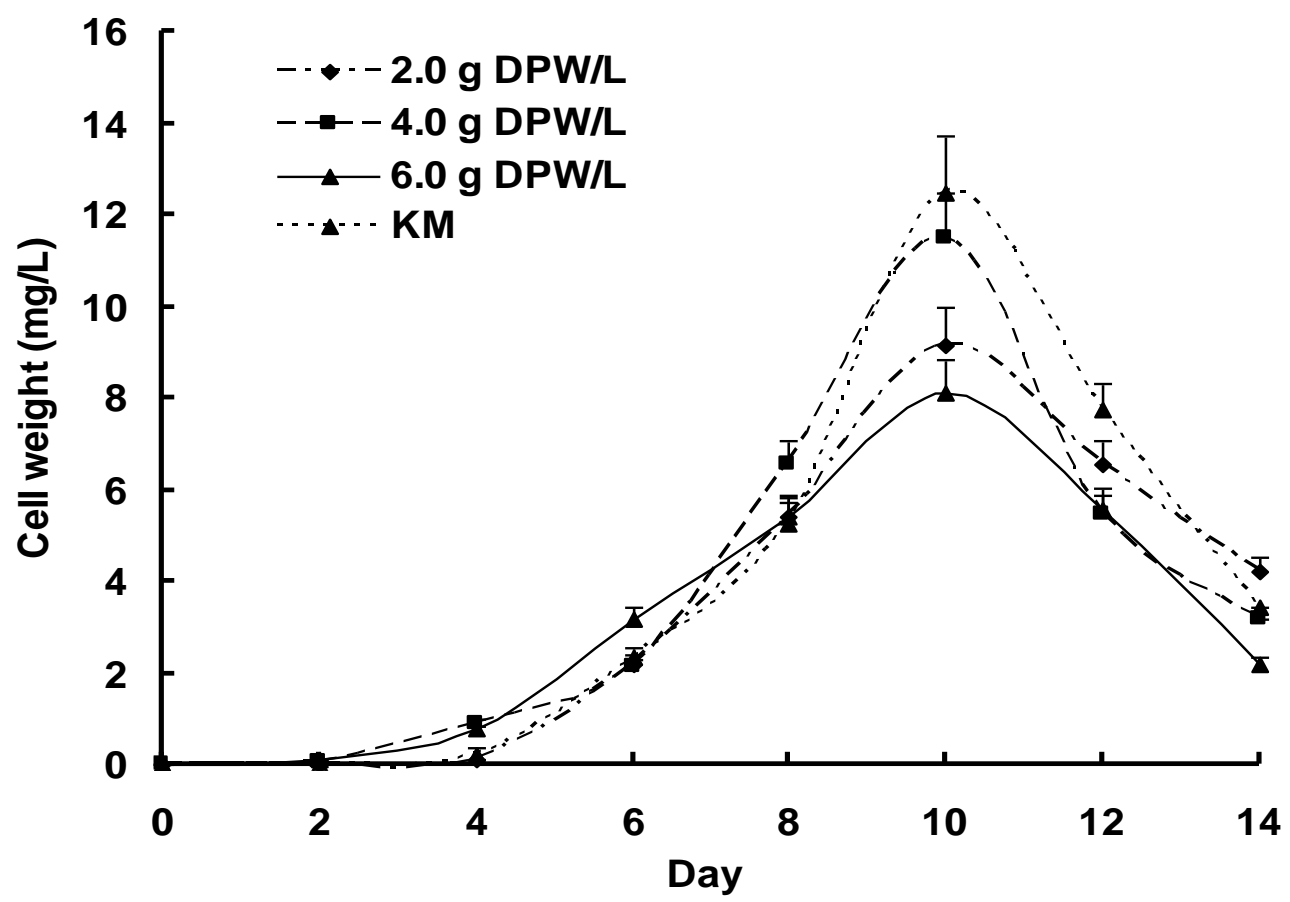

Fig. 6. Mean values of cell weight (mg/l) of Spirulina platensis grown in supernatant of three different digested poultry waste, and Kosaric medium. Vertical bars represent standard errors.

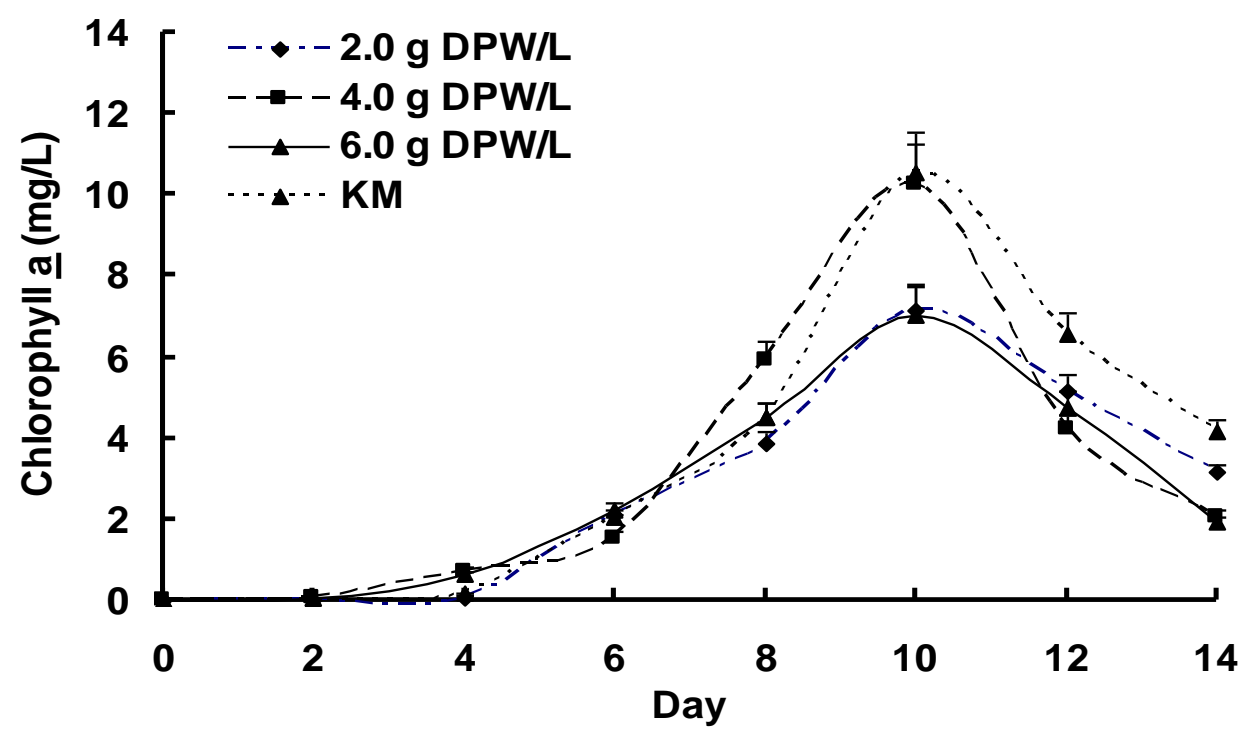

Fig. 7. Mean values of chlorophyll a $(\mathrm{mg} / \mathrm{l})$ of Spirulina platensis grown in supernatant of three different digested poultry waste and Kosaric medium. Vertical bars represent standard errors. 


\section{International Journal of Current Science Research and Review}

ISSN: 2581-8341

Volume 04 Issue 04 April 2021

DOI: 10.47191/ijesrr/V4-i4-08, Impact Factor: 5.825

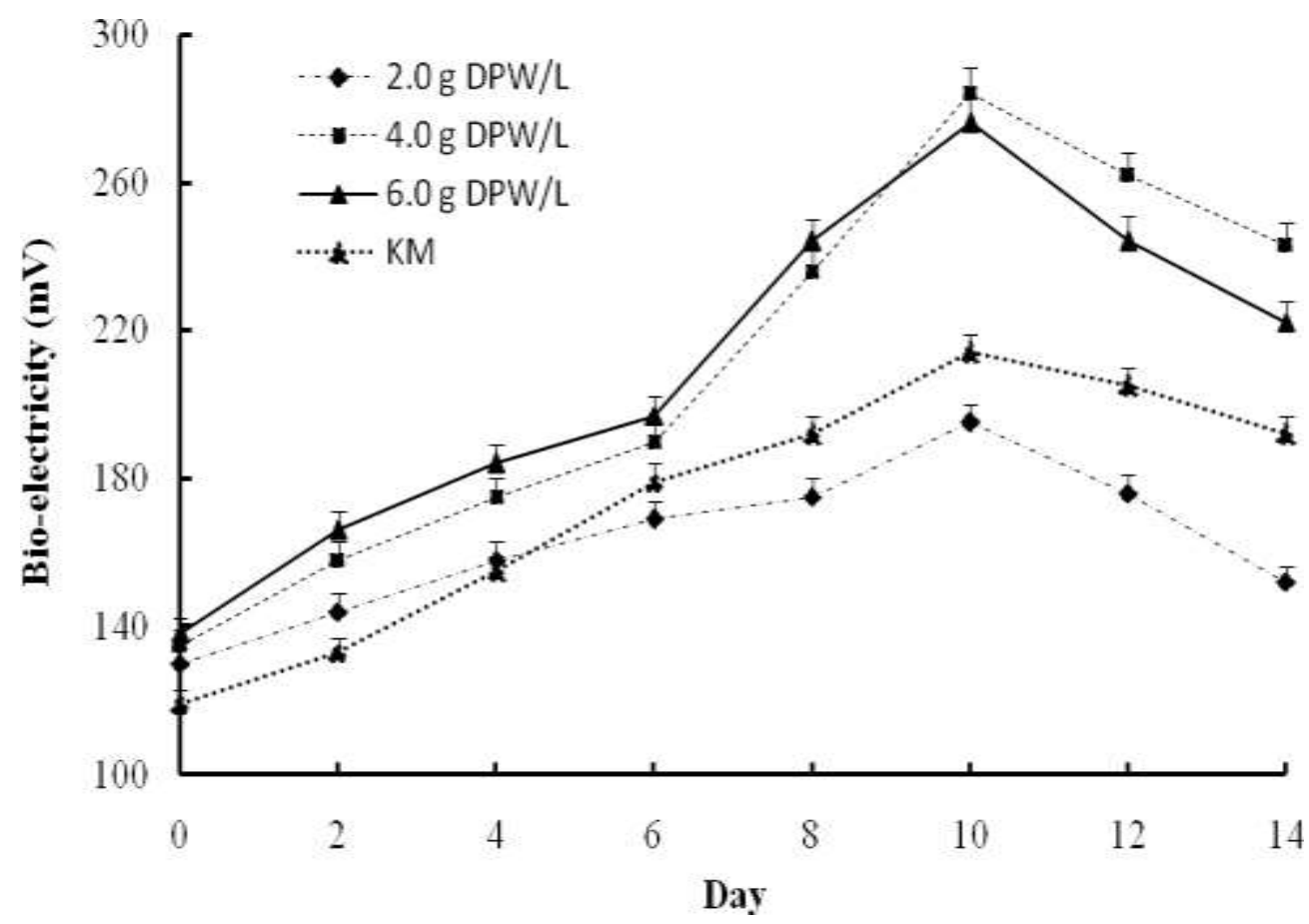

Fig. 8. Mean values of bio-electricity production during culture of Spirulina platensis in supernatant of three different digested poultry waste, and Kosaric medium. Vertical represent standard errors.

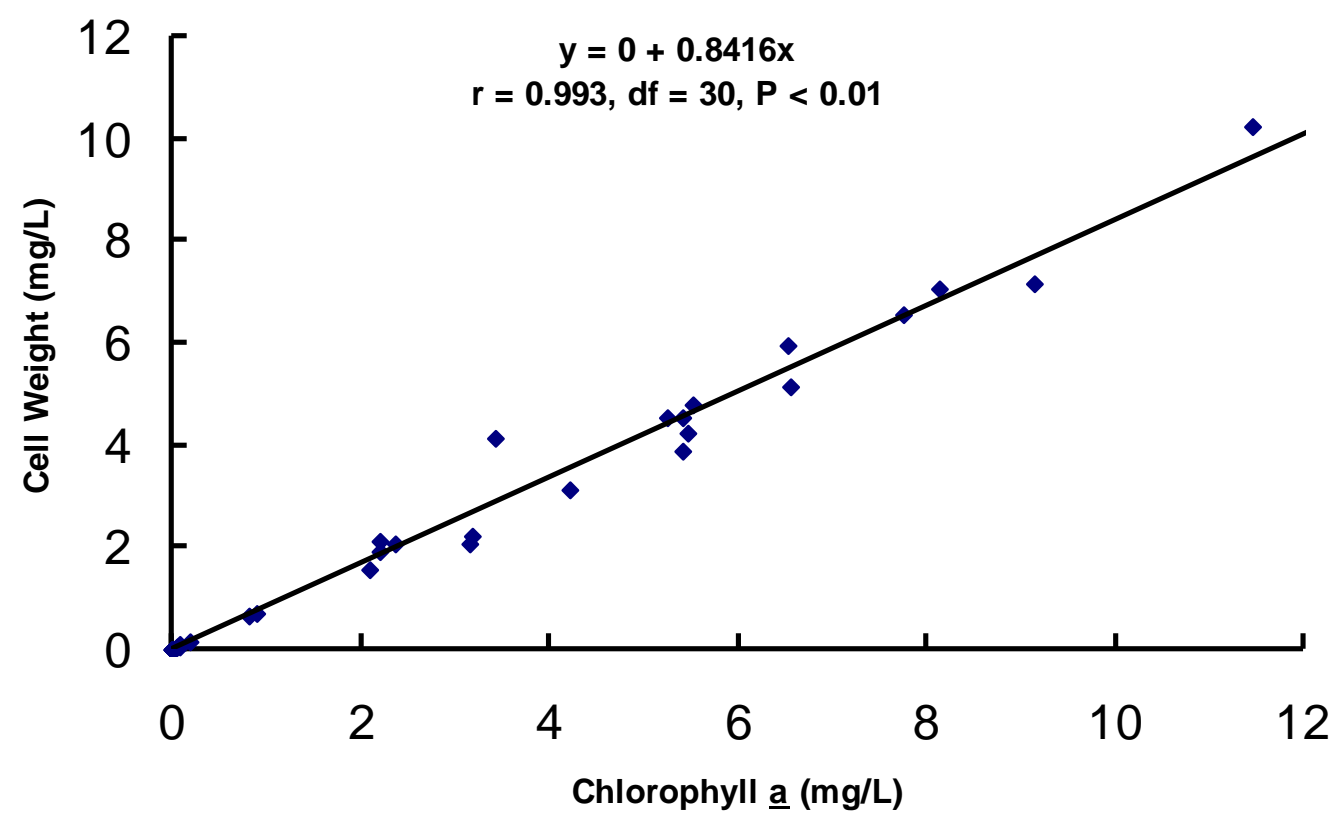

Fig. 9. Correlation coefficient (r) of cell weight $(\mathrm{mg} / \mathrm{l})$ of Spirulina platensis with chlorophyll a $(\mathrm{mg} / \mathrm{l})$ of spirulina grown in supernatant of three digested poultry waste, and Kosaric medium. 
ISSN: 2581-8341

Volume 04 Issue 04 April 2021

DOI: 10.47191/ijcsrr/V4-i4-08, Impact Factor: 5.825

IJCSRR@ 2021

Www.ijcsrr.org

\section{REFERENCES}

1. Abouelezz, F.M.K. 2017 Evaluation of spirulina algae (Spirulina platensis) as a feed supplement for Japanese quail: nutritional effects on growth performance, egg production, egg quality, blood metabolites, sperm-egg penetration and fertility. Egyptian Poul. Sci. 37(3), 707-719.

2. Clesceri, L.S., Greenberg, A.E., and Trussell, R.R. (eds.) 1989 Standard Methods of the Examination of Water and Wastewater. 17th edn. American Public Health Association, American Water Works Association and Water Pollution Control Federation, 1015 Washington, DC, USA, pp. 10-203.

3. Habib, M.A.B., Parvin, M., Huntington, T.C., and Hasan, M.R. 2008 Global Review on Culture, Production and Use of Spirulina as Food for Humans and Feed for Domestic Animals and Fish. TC Huntington (Editor), Report Number GF FIRID. RA2IP02000600. Food and Agriculture Organization (FAO) of United Nations, Rome, Italy, pp. 33.

4. Phang, S.M., Miah, M.S., Chu, W.L., and Hashim, A. 2000 Spirulina culture in digested sago starch factory waste water. J. Appl. Phycol. 12, 395-400.

5. Becker, B.W. 2007 Micro-algae as a source of protein. Biotech. Adv. 25, 207-210.

6. Jais, N.M., Mohammed, R.M.S.R., Al-Gheethi, A.A., and Hashim, M.K.A. 2016 The dual role of phycoremediation of wet market wastewater for nutrients and heavy metal removal and microalgae biomass production. Clean Tech. Envir. Policy, Cross Mark. DOI: 10.1007/s 10098-016-1235-7.

7. Sarr, S.M., Fall, J., Thiam, A., and Barry, R.O. 2019 Growth and survival of red tilapia (Oreochromis aureus x Oreochromis mossambicus) fry fed on corn and soy meal, peanut meal and fishmeal enriched with spirulina (Spirulina platensis). Inter. J. Agri. Policy Res. 7(1), 1-9.

8. Vetayasuporn, S. 2004 The potential for using waste water from household scale fermented Thai rice noodle factories for cultivating Spirulina platensis. Pakistan J. Biol. Sci. 7(9),1554-1558.

9. Usharani, G., Stella, D., and Saranraj, J.P. 2012 Mass cultivation of Spirulina platensis using agroindustrial effluent. LAP LAMBERT Academic Publishing GmbH \& Co., Germany, pp. 1-83.

10. Mia, M.L., Habib, M.A.B., Rahman, M.M., Hoque, N., Islam, M.S., and Al-Asif, A. 2018 Use of liquid rice starch as asource of carbon for growth of Spirulina platensis. J. Fish. Life Sci. 3(2): 34-45.

11. Rahman, M. M., Mia, M., Sarker, B., Fakhruddin, M., Habib, M.A.B., Karim, M.R., and Hoque, N. 2018 Evaluation of rotten orange as a source of inorganic nutrients for blue green algae, Spirulina platensis culture. Asian-Australasian J. Biosci. Biotech. 3(3), 208-224.

12. Habib, M.A.B., Munni, M.S., and Ferdous, Z. 2019 Culture and production of spirulina (Spirulina platensis) in supernatant of digested rotten potato. Bangladesh J. Fish. 31(1), 57-66.

13. Akter, L., Habib, M.A.B., Bablee, A.L., and Haque, M.I.M. 2019 Growth performance and estimation of single celled protein in spirulina (Spirulina platensis) cultured in supernatant of digested rotten apple (Malus domestica). Bangladesh J. Fish. Res., 19(1-2), 47-66.

14. Sarker, S.R., Azad, K.N., and Habib, M.A.B. 2019 Culture and growth performances of Spirulina Platensis in supernatant of digested rotten wax gourd (Benincasa hispida). Book of Abstract. Fisheries Society of Bangladesh Biennial Conference, Faculty of Fisheries, Bangladesh Agricultural University, Mymensingh, p. 125.

15. Baten, M.A., Ferdous, Z., and Habib, M.A.B. 2019 Culture and growth performance of Spirulina Platensis in the media prepared from supernatant of digested biscuit factory waste. Book of Abstract. Fisheries Society of Bangladesh Biennial Conference, Faculty of Fisheries, Bangladesh Agricultural University, Mymensingh, p. 124.

16. Muys, M., Sui, Y., Schwaiger, B., Lesueur, C., Vandenheuvel, D., Vermier, P., and Vlaeminck, S.E. 2019 High variability in nutritional value and safety of commercially available Chlorella and Spirulina biomass indicates the need for smart production strategies. Biores. Tech. 275, 247-257.

17. Dineshkumar, R., Narendran, R., and Sampathkumar, P. 2016 Cultivation of Spirulina platensis in different selective media. Indian J. Mar. Sci. 45(12), 1749-1754.

18. Lu, J., and Takeuchi, T. 2004 Spawning and egg quality of tilapia Oreochromis niloticus fed solely on raw Spirulina throughout three generation. Aquaculture 23(4): 625-640. 


\section{International Journal of Current Science Research and Review}

ISSN: 2581-8341

Volume 04 Issue 04 April 2021

DOI: 10.47191/ijcsrr/V4-i4-08, Impact Factor: 5.825

IJCSRR@ 2021

Www.ijcsrr.org

19. Sotiroudis, T.G., and Sotiroudis, G.T. 2013 Health aspects of Spirulina (Arthrospira) microalga food supplement. J. Serbian Chem. Soc. 78(3): 395-405.

20. Ayachi, S., El-Abed, A., Medhioub, A., Brouers, M., and Marzouk, B. 2004 Influence of temperature and light intensity on fatty acid composition during the development of spirulina, Arthrospira platensis. Rivista Italiana delle Sost. Grasse 81(3): 185-190.

21. Anbarasan, V., Kumar, V.K., Kumar, P.S., and Venkatachalam, T. 2011 In vitro evaluation of antioxidant activity of blue green algae, Spirulina platensis. Inter. J. Pharma. Sci. Res. 2(10), 2616-2618.

22. Raji, A.A., Alaba, P.A., Yusuf, H., Bakar, N.H.A., Taufek, N.M., Muin, H., Alias, Z., Milow, P., and Razak, S.A. 2018 Fishmeal replacement with Spirulina platensis and Chlorella vulgaris in African catfish (Clarias gariepinus) diet: Effect on antioxidant enzyme activities and haematological parameters. Research in Veterinary Science 119, 67-75.

23. Ghattas, T.A., Dawoud, E.N., Mahrous, A.F., and Elgabry, E.A. 2019 Effect of Spirulina Platensis supplementation on growth, some biochemical and immunological parameters in suckling calves. J. Egypt Nat. Med. Assoc. 79(2), 443-460.

24. Rosas, V.T., Manserrat, J.M., Bassonart, M., Magnone, L., Romano, L.A., and Tesser, M.B. 2019 Comparison of ßcarotene and spirulina (Spirulina platensis) in mullet (Mugil liza) diets and effects on antioxidant performance and fillet colouration. J. Appl. Phycol. DOI.org/101007/s10811-019-01773-1.

25. Venkataraman, L.V., and Beckar, E.W. 1986 Prospects of cultivated fresh and brackish water algae. CFTRI, Mysore, India, pp. 72-74.

26. Maeda, S., and Sakaguchi, T. 1990 Accumulation and detoxification of toxic metal elements by algae. Pages 109-136 in I. Akatsuka (Ed.). Introduction to Applied Phycology SPB Academic Publishing, The Hague, Holland.

27. Doshi, H., Ray, C.J., and Kothari, I.L. 2009 Live and dead Spirulina sp. to remove arsenic (V) from water. Inter. J. Phytoremed. 11, 53-64.

28. Khan, A.N.M.A.I., Habib, M.A.B., and Hossain, M.S. 2018a Chemical characteristics of different concentrations of sugarcane industry wastes for algal culture. Inter. Fish. Aquatic Res. 3(2), 21-24.

29. Stunda-Zujeva, A., and Rugiele, K. 2018 Growing and drying Spirulina/Arthrospira for producing food and nutraceuticals. Key Eng. Materials 762: 134-140.

30. Becker, B.W., 1984 Production and utilization of the blue-green algae Spirulina in India. Biomass 4, 105-125.

31. Alvarenga, R.R., Rodrigues, P.B., Cantarelli, V. de S., Zangeronimo, M.G., Jứnior, J.W. de S., da Silva, L.R., dos Santos, L.M., and Pereira, L.J. 2011 Energy values and chemical composition of spirulina (Spirulina platensis) evaluated with broilers. Revista Brasileira de Zootecnia 40(5), 992-996.

32. Zahroojian, N., Moravej, H., and Shivazad, H. 2013 Effect of dietary marine algae (Spirulina platensis) and production performance of laying hens. J. Agri. Sci. Tech. 15, 1353-1360.

33. Abed, E., Ihab, A.N., Suliman E., and Mohammad, A. 2016 Impact of spirulina on nutritional status, haematological profile and anaemia status in malnourished children in the Gaza strip: Randomized clinical trial. Mater. and Pedia. Nutri. J. 2(2). DX.DOI.org/10.4172/mpn.1000110.

34. Khalila, H.S., Fayed, W.M., Mansour, A.T., Srour, T.M., Darwish, S.I., and Nour, A.M. 2018 Dietary supplementation of spirulina, Arthrospira platensis, with plant protein sources and their effects on growth, feed utilization and histological changes in Nile tilapia, Oreochromis niloticus. J. Aquaculture Res. Dev. 9(10), 1-9.

35. Satter, A. 2017 Culture and production of housefly larvae and Spirulina using poultry waste, and their use as food for catfish post-larvae, PhD Thesis, Department of Aquaculture, Bangladesh Agricultural University, Mymensingh, Bangladesh, pp. 143.

36. Habib, M.A.B. 1998 Culture of selected microalgae in rubber and palm oil effluents and their use in the production of enriched rotifers. A Ph. D thesis submitted to the Faculty of Biology and Environmental Studies, University Putra Malaysia, Malaysia, pp. 530.

37. Habib, M.A.B., Yusoff, F.M., Phang, S.M., Kamaruddin, M.S., and Mohamed, M.S. 1998 Chemical characteristics and essential nutrients of agroindustrial effluents in Malaysia. Asian Fish. Sci. 11, 279-286. 
ISSN: 2581-8341

Volume 04 Issue 04 April 2021

DOI: 10.47191/ijcsrr/V4-i4-08, Impact Factor: 5.825

IJCSRR@ 2021

Www.ijcsrr.org

38. Sukumaran, P., Nulit, R., Halimoon, N., Simoh, S., Omar, H., and Ismail, A. 2018 Formulation of cost-effective medium using urea as a nitrogen source for Arthrospira platensis cultivation under real environment. Annual Res. Rev. in Biol. 22(2), 1-12.

39. Khatun, R., Noor, P., Akhtar, N., Jahan, M.A.A., Hossain, M., and Munshi, J.L. 2006 Spirulina culture in Bangladesh XI: Selection of a culture medium, suitable for culturing a local strain of Spirulina. Bangladesh J. Sci. Ind.. Res. 41(3-4), 227-234.

40. Soydemir, G., Keris-Sen, U. D., Sen, U., and Gurol, M. D. 2015 Biodiesel production of mixed microalgal culture grown in domestic wastewater. Bioprocess Biosystem Eng. 39, 45-51.

41. Hernández-Fernández, F.J., de los Ríos, A. P., Salar-García, M. J., Ortiz-Martínez, V.M., Lozano-Blanco, L. J., Godínez, C., and Quesada-Medina, J. 2015 Recent progress and perspectives in microbial fuel cells for bioenergy generation and wastewater treatment. Fuel Proc. Tech. 138, 284-297.

42. Liu, W., Cheng, S., Sun, D., Huang, H., Chen, J., and Cen, K. 2015 Inhibition of microbial growth on air cathodes of single chamber microbial fuel cells by incorporating enrofloxacin into the catalyst layer. Biosensors \& Bioelectronics 72 , 44-50.

43. Thong, C.H., Phang, S. M., Ng, F.L., Periasamy, V., Ling, T. C., Yunus, K., and Fisher, A. C. 2019 Effect of different irradiance levels on bioelectricity generation from algal biophotovoltaic (BPV) devices. Energy Sci. Eng. Doi: 10.1002/ ese3. 414.

44. Parvin, M., and Habib, M.A.B. 2005 Growth performance of Chlorella ellipsoidea as biomicrocapsule using supernatant of digested sugar mill waste effluent. Bangladesh J. Fish. Res. 9(2): 175-184.

45. Horwitz, W. (ed.) 1984 Official methods of Analysis of the Association of Official Analytical chemists. 14th Edn. Association of Official Analytical Chemists, Washington, DC, USA, pp. 1018.

46. Zarrouk, C. 1996 Contribution a 1'etude d'une cyanophycee. Influenced de diverse facteures physiques et chimiques sur la crossace et al. photosynthese de Spirulina maxima (Setch. Et Gardner) Geitler. PhD thesis (in French), University of Paris, France, pp. 412.

47. Bold, H.C., and Wynne, M.J. 1978 Introduction to the Algae, Structure and Reproduction. 2nd edition, Prentice-Hall, Inc., Englewood Cliffs, New Jersey, USA, pp.706.

48. Yamaguchi, T. 1992 Plankton Algae in Taiwan (Formosa). Uchida Rokakuho, Tokyo, Japan, pp. 252.

49. Vymazal, J. 1995 Algae and Element Cycling in Wetlands. Inc. Boca Raton, Florida, USA, pp. 689.

50. Phang, S.M., and Chu, W.L. 1999 University of Malaya Algae Culture Collection (UMACC). Catalogue of Strain. Institute of Postgraduate Studies and Research, University of Malaya, Kuala Lumpur, Malaysia, pp. 77.

51. Habib, M.A.B., Nony, A., and Orpa, M.F. 2021 Smart culture of spirulina using supernatant of digested rotten tomato (Solanum lycopersicum) to produce protein, bio-fuel and bio-electricity. I. J. Curr. Sci. Res. Rev. 4(3), 186-194.

52. Zar, J.H. 1984 Biostatistics. Prentice-Hall, Inc., Englewood Cliffs, New Jersey, USA, pp.718.

53. Ghofar, H.S.A., Jahromi, M.J., Ikhsan, F.N.M., and Samsudin, A. A. 2019 The effects of varying dilution levels of wastewater on the cultivation of Spirulina sp. Malaysian J. Anim. Sci. 22(1), 25-33.

54. Cheirsilp, B., and Louhasakul, Y. 2013 Industrial wastes as a promising renewable source of production of microbial lipid and direct transesterification of the lipid into biodiesel. Biores. Techn.142, 329-337.

55. Soletto, D., Binaghi, L., Lodi, A., Carvalho, J.C.M., and Converti, A. 2005 Batch and fed-batch cultivations of Spirulina platensis using ammonium sulphate and urea as nitrogen sources. Aquaculture 243, 217-224.

56. Wicaksono, H.A., Satyantini, W.H., and Masithah, E.D. 2019 The spectrum of light and nutrients required to increase the production of phycocyanin in Spirulina platensis. Presented in the 1st International Conference on Fisheries and Marine Science. IOP Conference Series. Earth Envir Sci. 236 012008. DOI: 10.1088/ 1755-1315/236/1/012008

57. Habib, M.A.B., Yusoff, F.M., Phang, S.M., and Mohamed, S. 2003 Growth and nutritional values of Moina micrura fed on Chlorella vulgaris grown in digested palm oil mill effluent. Asian Fish. Sci. 16(1-2), 107-119.

58. Alam, A.K.M.K. 2005 Growth performance of Spirulina platensis in different concentrations of fermented pond bottom soil. M.S. thesis. Department of Aquaculture, Bangladesh Agricultural University, Mymensingh, Bangladesh, 81 pp. 


\section{International Journal of Current Science Research and Review}

ISSN: 2581-8341

Volume 04 Issue 04 April 2021

DOI: 10.47191/ijcsrr/V4-i4-08, Impact Factor: 5.825

IJCSRR@ 2021

www.ijcsrr.org

59. Dey, B.K. 2004 Culture and growth performance of Spirulina platensis in various concentrations of mustard oil cake medium. M.S. thesis. Department of aquaculture, Bangladesh Agricultural University, Mymensingh, Bangladesh, pp. 68.

60. Habib, M.A.B., and Kohinoor, A.H.M. 2018 Culture and production of house fly larvae and spirulina using poultry waste and their use as food for catfish post-larvae. Report on Advanced Research. Grants for Advanced Research in Education, Secondary and Higher Education Division, Ministry of Education, Government of the Peoples' Republic of Bangladesh, Vol. 2, Chapter 2, pp. 66-70.

61. Tantichareon, M., Bhumiratna, S., Jeyashoke, N., Bunnag, B., Reungjitchawaly, M., Chitnumsub, P., Watawin, G., and Lettriluck, S. 1991 The culture of Spirulina using tapioca starch wastewater. In: Goh, S.M., Chuah, C.H., Tong, S.L., Phang, S.M., Vikineswary, S. (Eds.), Proceedings of the Regional Seminar on Management and Utilization of Agricultural and Industrial Wastes, 1990. Univerdity of Malaya, Kuala Lumpur, Malaysia, pp. 136-140.

62. Chu, W.L., Phang, S.M., and Swee-Hock, G. 1995 Influence of carbon source on growth, biochemical composition and pigmentation of Ankistrodesmus convolutus. J. Appl. Phycol. 7, 59-64.

63. Khan, A.N.M.A.I., Habib, M.A.B., and Miah, M. I. 2020 Effects of inorganic media enriched with sodium acetate on the growth performance and nutrient content in the microalga Chlorella vulgaris. J. Fish. and Envir. 44(3), 32-44.

Cite this Article: M.A. Satter, Maisha F. Orpa, M. Ahsan B. Habib (2021). Smart Production of Lipids as Bio-Fuel in Spirulina Platensis (=Arthrospira Fusiformis), and Bio-Oxygen and Bio-Electricity in Media Cultured in Supernatant of Digested Poultry Waste. International Journal of Current Science Research and Review, 4(4), 293-307 